- William Cotter

williamcotter@email.arizona.edu

\title{
Gaza at the margins? Legibility and indeterminacy in the Israel-Palestine conflict
}

Despite prominent attention to the nature of the state in the social sciences, the place of language in creating and maintaining the state remains an emerging area of research. The analysis that follows investigates indeterminacy and illegibility in messages disseminated by the Israeli military in the Gaza Strip. This analysis highlights the ways in which linguistic indeterminacy is used as a tool by the state in controlling populations at its margins, while investigating the role of language in reproducing the state through the circulation of texts.

Introduction: Important statement for the residents of the Gaza Strip ${ }^{1}$

$\mathrm{F}$

or decades, state-sponsored violence has been an area of major concern within human rights circles. Law and political science scholars have treated state violence through analyses of the legality and efficacy of state methods, while at the same time historians have re-analyzed periods of state violence, at times challenging official state discourses (see Levine 2005; Morris 2008; and Pappé 2006 for the case relevant to this analysis). Anthropologists have also contributed to investigating the effects of violence in daily life (e.g. Green 1999; Scheper-Hughes 1993) and various forms of violence in relation to the state (Das et al 2000). However, engagement from within linguistic anthropology on language within systems of violence remains an emerging area of research (Faudree 2012; Gavriely-Nuri 2013; Hodges 2011). One potential site of linguistic anthropological engagement with broader anthropological discussions on violence is analysis of the forms of communication that take place between state militaries and civilians in conflict. This type of analysis highlights how language and violence intersect, along with the means by which language becomes one part of a larger constellation of methods used to reproduce and reinforce the sovereignty of the state itself.

Communicative acts between states and civilians in war manifest in a variety of different forms. In the Gaza Strip - the geo-political context at the center of this study - these acts take the form of SMS messages and phone calls sent by Israeli intelligence officers through Gazan telecommunications networks and military leaflets dropped over Gaza (Tawil-Soury 2013; Weizman 2009a, 2009b). These forms of discourse represent direct methods of communication between the military, as an extension of the state, and Palestinian civilians in Gaza. However, this communication only travels top-down, from abstracted state structures to civilians in war.

Journal of Linguistic Anthropology, Vol. 27, Issue 1, pp. 1-18, ISSN 1055-1360, EISSN 1548-1395. Copyright C 2017 American Anthropological Association. DOI: 10.1111/jola.12147. 
The analysis that follows investigates textual indeterminacy (Falk-Moore 1978, Irvine 1996, Jaffe 2009) in the participant frameworks of SMS messages and leaflets disseminated by the Israeli military within the context of the three most recent rounds of violence in the Gaza Strip: Operation Cast Lead (2008-9), Operation Pillar of Defense (2012), and Operation Protective Edge (2014). My analysis begins with a seven-word SMS message sent by the military to a resident of Gaza during Operation Pillar of Defense. Through the SMS message we establish the initial layers of indeterminacy that are then built upon by the subsequent analysis of a series of military leaflets used in Gaza.

The textual data presented in this study was collected from varied international news organizations including NBC, Maan, and Haaretz, all of whom reported on the three most recent outbreaks of full fledged conflict in Gaza. As one component of their reporting, news outlets regularly publish the texts (often as photographs) of leaflets or SMS messages when writing about the development of the conflict. In addition, the Israeli Defense Forces, on its official website and blog, regularly publish copies of leaflets dropped over Gaza.

Gaza represents an unfortunately well-suited case study for the type of analysis that I present below. Near continual cycles of military conflict in the Strip have created a situation in which discourses about these conflicts circulate (Spitulnik 1997) in both local and international media and in daily discourse(s) in Israel and the Occupied Palestinian Territories (Gavriely-Nuri 2013). Additionally, the Israeli state has been involved in more military conflicts than any other Western state following the Second World War (Gavriely-Nuri 2015, 4). Due to the heightened attention the Israel-Palestine conflict receives, the frequency with which conflict takes place, and the undeniable power imbalance between belligerents in the conflict, an atmosphere exists where communication between the military and civilians has become commonplace. Beyond its commonality in this context, I argue that language has become a central tool in managing not only conflict but the ways in which the Israeli state solidifies itself as a recognized democracy within the international community.

In the analysis below, leaflets and SMS messages are presented in transliterated Arabic alongside an English translation carried out based on the photographed copies of these texts that were reported in the media. These examples were chosen for their wide circulation in international media, the quality of the documentation of the texts themselves, and because they highlight the broad range of indeterminacies that are present in these forms of military-to-civilian communication in Gaza, providing a more holistic view of the role of language in one of the world's most enduring conflicts. Beyond these textual examples, fieldwork that I conducted in the Gaza Strip in 2013, six months after Operation Pillar of Defense and just over a year before Operation Protective Edge, provides an ethnographic backdrop for these discursive acts.

My aim in analyzing a specific set of texts, from a single context, is to show how language can be utilized by states and their ancillaries in times of conflict. But beyond simply examining the ways in which a given state or its military uses language, what this analysis offers us is a way to understand how language traverses the margins of the state and can serve as a source of political and social power in the maintenance of sovereignty. As this analysis shows, in Gaza the margins of the state are penetrated with discourses that create a vision of an Israeli state that appears wildly illegible (Das 2004; Das and Poole 2004) and contradictory to civilians caught in fighting. The textual representations of the state analyzed below are shot through, to draw on Bakhtin's (1981) turn of phrase, with indeterminacies that come in the form of ambiguity and unusable information that challenges the forms of order and rationality that have been treated as hallmarks of the state (Das and Poole 2004, 5).

While in contrast, at a national or international level, the state uses the marginality of Gaza and the language of these texts to ascribe notions of democratic order, legality, and humanitarianism to the state. The result is a duality where the state is 
rendered both legible and illegible, while Gaza is continually situated as the location of disorder, a space in which the state must necessarily impose itself (Das and Poole 2004, 6). However, by examining these representations of the state we see that despite attempts to keep it at its margins, Gaza and the "forms of illegibility, partial belonging, and disorder that seem to inhabit the margins of the state" (Das and Poole $2004,6)$ ultimately constitute a necessary condition of the Israeli state as both a theoretical and political object. At the same time, as Tawil-Soury and Matar have described, Gaza is unique in that it continually reinstates its centrality, providing "a vivid and painful contemporary example of the violence and enmity of modern warfare $(2016,2)$.

\section{From the Requerimiento to Gaza}

While situating language in modern military conflict may represent a relatively novel area of interest, analyses of language within the context of state violence are not new. The Spanish Requerimiento (Hanke 1949; Helps 1971) is one of a number of cases where state actors that have utilized language in framing, threatening, and ultimately carrying out acts of violence. As Faudree notes (2012, 182-83), the Requerimiento were a collection of written texts used by the Spanish to formalize their conquest of the Americas. The texts formally demanded that indigenous peoples submit to the rule of Spain, demands made under the threat of violence if the calls of the texts went unheeded (Faudree 2012, 183). In her analysis of the Requerimiento, Faudree lays out four constituent parts of the structure of the texts (Faudree 2012, 188):

1 Recounting of [Western] history, from creation through Papal donation

2 Explanation of Spanish authority to evangelize in the New World

3 Plea for the natives to submit to the Crown and permit evangelization

4 Promise of war if the natives do not submit

Faudree suggests that the participant framework of the texts is established most clearly in the second half. Beginning in the third section, the text explicitly requests the submission of native peoples to Spain. The fourth section, while describing the consequences of resistance, also effectively constitutes the larger social hierarchy that the texts establish (Faudree 2012, 188-89), a situation where through their structure the texts both "describe and instantiate" a specific social hierarchy (Faudree 2012, 188-89; Silverstein 1981, 9). Faudree argues that "the entire narrative aims to create, through key speech acts, a specific configuration of socio-political relations by describing them...The text's form is thus a key part of the process by which Spanish authority is simultaneously indexically presupposed and indexically created" (Faudree 2012, 189). A similar structure can be discerned from the language used by the Israeli military in the Gaza texts presented below. The texts highlight linguistic practices, which reify the vision of a militarily powerful, but ultimately democratic, Israeli state alongside a Gaza that is continually situated as disorderly and under the control of decidedly undemocratic non-state actors.

Through communicative acts that establish an indeterminate and shifting participant framework, the state draws Gazan civilians into a complex relationship with its military. This relationship positions civilians as both metaphorical and literal intermediaries in shadow conversations (Irvine 1996) taking place between Palestinian fighters and the state. These conversations take place outside of the strict bounds of the texts, but coupled with the indeterminacies contained therein constitute a larger body of discourse circulating between the military and resistance organizations on the ground in Gaza. In doing so, SMS messages sent to cellular phones eliminate the distance between civilians and abstract apparatuses of state-power, creating a form of intimacy wherein a direct line of communication with the state is being carried around in the pocket of Gaza's 
residents. Military leaflets falling over parts of Gaza during conflict, littering already crowded streets, are manifestations of the conflict that engage Gazans on multiple sensory levels: they can be picked up, read, used as fuel for fires during electricity shortages, or left to cover the ground until the conflict temporarily recedes.

Along with this constructed sense of intimacy we can also view the distance between the state and civilians as growing through the use of these linguistic practices. By delivering these texts remotely, the military creates physical distance between itself and civilians on the ground. This is coupled with the reality that leaflets are delivered by the same machines that may later drop munitions on Gaza. The duality of these machines in serving two contrastive purposes is in effect a manifestation of the indeterminacy that falls out from the texts examined in this study. As I highlight below, Israeli discursive engagement with Gazan civilians forms a complex interplay of indeterminacies. The result of this interplay renders the state illegible to civilians through ambiguous textual practices and the utilization of overly general (and thus ineffective) information in the texts, but legible, democratic, and humanitarian within the broader international community through the provision of what is argued to be an effective warning. My analysis begins with a seven-word SMS message sent by the Israeli military to a resident of Gaza during the 2012 conflict. Through the SMS we establish the initial layers of indeterminacy that are then built upon by the subsequent analysis of a series of military leaflets used in Gaza.

\section{Touching the backbone: Gaza's telecommunications infrastructure as a military tool}

During Operation Pillar of Defense in November 2012, Rana Baker, a freelance journalist in Gaza, reported that her father received an SMS message from the Israeli Defense Forces (IDF). Although to a Western audience, receiving an SMS message from the military is unheard of, this is not unexpected in Gaza. By 2012, hacking of Palestinian communications networks by Israeli military and intelligence officers had become an established practice. Similar methods were used during Operation Cast lead in 2008-9, with as many as 250,000 calls being made to Gazan Palestinians, and text messages sent to most cellular phones in Gaza by the military (Amnesty International 2009; Tawil-Soury 2013, 80; Weizman 2009b).

The ability of Israeli intelligence officials to tap into and make use of the Gazan telecommunications infrastructure is one manifestation of what Tawil-Soury (2013) terms the "digital occupation" and "high-tech enclosure" of the Gaza Strip. This type of control is made possible through the architecture of Gaza's communications network that has Israel as its main technological support structure. Tawil-Soury describes $(2013,58)$ that:

A telephone call made on a landline, even between Gaza City and Khan Younis, is physically routed through Israel. Internet traffic is routed through switches located outside the Gaza Strip. Even on the ubiquitous cellular phones, calls must touch the Israeli backbone at some point. Like much else about the Gaza Strip, telecommunication infrastructures are limited by Israeli policies.

In spite of the commonality of the practice, visual data of the content of these SMS messages is challenging to obtain. For clarity, the SMS message is presented below in transcription and an English translation: ${ }^{2}$

Example 1: The next phase is coming, Operation Pillar of Defense (2012) ${ }^{3}$

al-marhala al-muqabala qa:dima ibta'adu: 'an 'ana:șir hama:s

"The next phase is coming, distance yourselves from Hamas elements." 
The SMS message was written in Standard Arabic, a code choice recurrent throughout all of the texts examined in this analysis. Standard Arabic, although spoken natively by none of Arabic's 300 million speakers, is the default written form of Arabic. It is the language of literature, news, and official forms of government communication (see Holes 2004). In addition to the prominent place of Standard Arabic in institutional frameworks, the dialects of Arabic are also rarely codified in writing. ${ }^{4}$ This makes Standard Arabic the default code for these texts, which can be viewed as part of a larger body of "official" government discourse. ${ }^{5}$

Although Standard Arabic is a default for written Arabic, use of this variety presupposes that the recipient is able to comprehend the message. Despite strong Palestinian education rates, with literacy rates rising rapidly in more recent years, cycles of violence and economic disparity over the past three decades have resulted in the gradual collapse of educational infrastructure in the Gaza Strip (Roy 2007, 228 \& 292). Children, the elderly, and women in Gaza show the highest degrees of illiteracy, which could, if they encounter these texts, require that they turn to their social networks in order to determine the meaning of the message, thus complicating their own ability to react quickly to the warnings that the texts contain. ${ }^{6}$

Both local media outlets covering the use of these methods and my own experience in Gaza speaking with civilians suggests that one primary issue with these messages is that civilians largely do not feel as if they can trust the information they contain. Despite the state's attestation that they provide regular and effective warnings to civilians of impending military action, a legacy of seemingly never-ending conflict creates an environment where there is little trust in the motives of the state. Civilians also suggest that another factor that renders these messages largely illegible is that the strikes that we will see mentioned in the remaining texts below often never materialize. In addition, many of the warnings distributed by the military in Gaza are sent across most of the territory, which Amnesty International $(2009,51)$ has argued renders them too general to constitute an effective warning. The result is what residents describe as a form of psychological warfare, where knowing what information is accurate, what (or who) may be targeted, or when operations may take place is never certain. Similar to what Das $(2004,227)$ has described with respect to the Indian state, in Gaza this ultimately reflects an instability between what the texts contain and the potential for the texts to manifest as military action.

Drawing on Faudree's (2012, 190-91) discussion on the referential indeterminacy of the Requerimiento, the fact that these SMS messages may not be understood or are too general to be useful, reflects that they may not have been the targets of the message. Looking outside of the immediate environment of Gaza, the content these messages suggests that the broader regional or international community may have been the ultimate recipients of the texts. This indeterminacy reflects how "language can be used by those who have (or wish to claim) power to prescribe while purporting to describe; to fix and define others while retaining all of the advantages of indeterminacy and all the maneuver room of processes of situational adjustment" (Jaffe 2009, 246). In this sense, the interplay between the illegibility of the texts to those on the ground and their simultaneous legibility in the international community provides the Israeli military with room to maneuver in wider international debates surrounding their actions during war. The use of Arabic here, regardless of whether or not it is understood, provides the military with the ability to say that it provided warnings to Gazan residents in their primary language of communication, an option that would not be available had the messages been sent in Hebrew or English, two other major languages of communication used in Israel.

In turn, the provision of a warning and the citability of these texts (Das 2004, 234) as they circulate in the international community supports Israeli state claims to the legitimacy of their actions in the conflict. The effectiveness of this tactic can be seen in the frequency with which the news organizations covering the use of this tactic highlight the nature of the texts as a warning to civilians. The only exceptions to this 
Journal of Linguistic Anthropology

framing of the data as a warning designed to help civilians came from reports published by Maan, a major local Palestinian news agency, and +972 magazine, an online magazine dedicated to opposing the Israeli occupation.

Moving beyond the issue of linguistic code and legibility, by looking more broadly at the events of Occupation Pillar of Defense we can reconstruct the temporal development of the conflict in relation to the SMS message. The 'prior phase' that the message alludes to began with an air strike that killed Ahmed Jabari, the head of Hamas' military wing in Gaza on November $14^{\text {th }}, 2012 .^{7}$ The SMS provides a warning of impending military action for the recipient. However, the time frame for "the next stage" remains ambiguous. This temporal indeterminacy makes it possible, as Jaffe (2009) notes, "to suggest without the risks of assertion; and with the benefits of after-the-fact denials or reconstruals of their meanings and stances" (243). Alongside this temporal indeterminacy, the use of the term 'ana:sir 'elements' adds a layer of lexical indeterminacy to the text by leaving the referent of an 'element' undefined, a point that will be investigated in more detail later in this analysis.

Alongside the overwhelming military power of the state, through the system of blockade that has been in place in Gaza since $2007^{8}$, the state has secured almost total control of the movement of aid, goods, and people in and out of the coastal territory. Through these discursive practices the state is able to provide warning to Gazan residents - an action that would be expected of a democratic actor engaged in armed conflict, while still maintaining control over both the territory and the temporal development of the conflict. This ability to control virtually all aspects of day-to-day life in Gaza, Halper's (2000) "matrix of control", also constitutes a larger strategic advantage for the military. The use of language in the texts examined here serves to further reinforce their position of power in the conflict, and their ability to control the development of the conflict by controlling the flow and form of information.

Interestingly, the participant framework created through this indeterminacy is ultimately as indeterminate as the SMS itself. On one level, the fact that this practice is commonplace and was used en masse across Gaza bleaches the message of any personal elements. On another level, Gazans are receiving SMS messages from the Israeli military, an extension of the state. This ability to carry out such an intensely personal act reflects the degree of power and control that the state has over Gaza's residents, a visual manifestation of the methods of digital control discussed previously (Tawil-Soury 2013).

This form of constructed intimacy is also one in which neither the recipient nor the addressee is clear. It is impossible to know who authored the message or their role in the conflict, but although the author is unidentified, the relationship itself is not completely indeterminate. The message that Baker's father received was likely part of a larger blast of SMS messages sent to many of the cellular phones in the Gaza Strip. Still, the military has the ability to target specific phones and individuals in particular areas of Gaza, as evidenced by the practice of calling civilians to alert them that their specific home has been marked for air strikes. ${ }^{9}$ The result is a practice that is, on one hand, delivered through both extremely personal and intimate methods-reaching civilians on their personal cellular phones - and impersonally, through language that reads as somber, devoid of emotion, and detached. The military's ability to reach individuals directly closes the gap between what are often abstract state power structures and the daily, lived experiences of those on the ground. What these texts and the methods by which they are delivered represents is the potential for the military to reach across boundaries that demarcate the traditional structure of the state (Poole 2004, 50). Ultimately, as these texts show, the distinction between the state's margin and its center is continually blurred, renegotiated, transgressed, and reconfigured (Poole 2004, 55).

Through the language of these texts and the forms of warning they contain, the Israeli military is able to position itself as democratic, moral, and just in the way it manages conflicts. Military strategy here works hand in hand with the indeterminacy of the participant framework of the conflict and the mapping of multiple different 
participant roles onto a given actor (Irvine 1996). Beyond this issue of positioning, the use of these texts also, in Das' terms, creates a situation in which Gazans are "pulled into the gravitational force of the state through the circulation of documents produced by its functionaries" $(2004,229)$. Within the Gaza context, the ultimate effect of this pull towards the center is that it nullifies claims by civilians of potential criminality of the state during times of conflict. To circulate a warning, even if it does not constitute an effective advanced warning within humanitarian frameworks (Amnesty International 2009) then "becomes proof of the 'legality' of the operations." (Das 2004, 240).

Moving to an examination of leaflets used in Gaza between 2008-2014, we can see that the military again takes on multiple roles, acting both with concern for civilians through the provision of a warning, but also with calculated language that serves larger state aims. However, by adding leaflets to this emerging picture of state communication in Gaza it becomes clear that through layered indeterminacies and the shifts in participant roles that result, civilians oscillate between belligerent and non-combatant, positioning them as intermediaries between resistance fighters and the state. One particular form of indeterminacy that facilitates these subtle shifts in the participant framework is the use of lexical indeterminacy tied to the notion of 'terrorist elements' within Gaza that are the stated targets of Israeli strikes.

\section{'anāșir: The replication of lexical indeterminacy across texts}

One consistent thread through the data presented in this analysis is the use of the lexical item 'ana:șir - 'elements'. However, what constitutes an element in these texts is rarely defined. Although it is reasonable to suspect that the IDF uses 'ana:șir to reference Hamas militants or installations, in a densely populated area like Gaza, what constitutes an 'element' is often not entirely clear. The choice of targets by the Israeli military in the past three conflicts also reflects that 'ana:șir may refer to obvious military targets such as rocket launching sites and resistance tunnels or training camps, but also seemingly innocuous sites such as homes, schools, hospitals, or United Nations facilities. As a result, the indeterminacy emerging from the use of 'ana:sir makes it challenging for civilians who receive these messages to follow their instructions.

As I have argued in relation to the SMS message discussed above, the indeterminacy of 'ana:sir provides moral or legal room for the military to conduct itself in conflict, while also reifying a specific image of the state within the international community. Continually framed as a warning to civilians, these texts form part of what is regularly described as a form of 'humanitarian war' being conducted in the Gaza Strip (Asad 2007; Weizman 2009b, 557; 2011). The use of language here couples with the use of forms of high technology, notably the ability to reach specific individuals on cellular phones, targeted assassination techniques that are said to reduce civilian casualties, and the increasingly ubiquitous tactic of 'knocking on the roof' ${ }^{\prime 10}$ during times of open conflict. As it is, couched within the broader discursive context of a warning, 'ana:șir puts in writing that targets exist, and that this has been communicated to civilians so that they can avoid them.

However, to civilians the continually shifting and seemingly arbitrary nature of what constitutes a 'terrorist element' renders the state largely illegible. This illegibility stems from the overly general nature of many of the warnings provided by the IDF in Gaza. Even in cases like those presented below where specific directions are given, human rights organizations have argued that these texts do not constitute effective advanced warnings within current international humanitarian frameworks (Amnesty International 2009) and make it challenging, if not impossible, for civilians to effectively judge the safest course of action. Still, the use of these forms of indeterminacy and, crucially, that they occur within a textual warning does not serve to challenge the idea of a democratic and humanitarian state carrying out conflict against a disordered, uncivilized, non-state actor at its margins (Das and Poole 2004, 6). 
This type of lexical indeterminacy and what it accomplishes can be grounded in another conflict: the United States drone warfare campaign (Benjamin 2013; Kaag and Kreps 2014). In the language of drone warfare, we see another example of how linguistic indeterminacy is used to the benefit of the state, reinforcing hierarchies of power while framing state military actions in broader humanitarian terms. A level of indeterminacy parallel to that of 'ana:șir is evident in what the United States military and Central Intelligence Agency have termed 'signature' drone strikes. These drone strikes are carried out on individuals, groups, or structures that carry the 'signature' of terrorist activity. However, the political and military actors involved in US drone operations have been reluctant to commit to a description of what constitutes the 'signature' of terror activity. The resultant indeterminacy keeps the referential meaning of the term opaque, allowing the military and CIA to more easily conduct themselves without having to fully define the scope of their operations.

These forms of indeterminacy and their efficacy reflect the extent of state power and control in situations of conflict. Through its superior military power, the United States is able to conduct the "War on Terror" (Hodges 2011) while leaving indeterminate the targets of war. In the Gazan context, through a complex web of indeterminacies the military is able to carry out strikes against militant groups while often not defining what the 'elements' are that civilians should avoid. To further exemplify this point, I turn now to a collection of military leaflets used in Gaza. These leaflets highlight that the indeterminacies in the SMS message analyzed not only provide the military with flexibility in conducting its operations, but also continually reposition civilians in differing relations to the military and to resistance groups operating in the Gaza Strip.

\section{Lend a helping hand to your brothers and sisters in the Strip: military leaflets in Gaza}

Compared to the sparse visual availability of SMS messages sent by the IDF to Gazan Palestinians, military leaflets constitute a larger body of data. The practice of dropping leaflets on both civilian and military areas during wartime is not new. Beginning on a large scale during World War I, leaflets have become a fairly well established method of alerting residents of an area of impending military actions, as well as playing a role in psychological warfare against enemy combatants (Taylor 2003, 188-90).

For this analysis I have selected four examples of military leaflets, all of which were collected from various international news reports about the use of this tactic by the Israeli military, as well as from the official IDF blog, which has regularly published information about the steps taken by the military to reduce civilian casualties in Gaza. ${ }^{11}$ The news sources were all major local and international news agencies, ${ }^{12} 1314$ and these specific examples were chosen because they best highlight the range of indeterminacies present within the discourse of military leaflets in Gaza. The data below is presented in two columns, with transcription on the left and a translation of the Arabic into English on the right.

Example 2: Take responsibility for your fate, Operation Cast Lead (2009) ${ }^{15}$

1. baya:n ha:mm li-sukka:n al-qita:'

2.

3. nmin ajli sala:matikum, tahlu: al-mus'u:liyya

4. 'an mași:rkum wa tajannabu: al-iqtira:b min

5. 'ana:șir hama:s wa mara:kiziha: allati sawfa

6. tu arridu haya:takum li-l-xațar. hama:s wa

7. marra uxra: taqu:d al-mintaqa 'ila: taș $i: d$
Important statement for the residents of the Strip

For your safety, take responsibility for your fate and avoid approaching Hamas elements and centers which will put your lives at risk. Hamas has once again led the area to military escalation and bloodshed and the Israeli 
8. 'askari: wa 'ila safik lil-dima:' 'inna jayš

9. al-difa:' al-'isra:'i:liyy 'a:zim 'ala hima:yat

10. sukka:n dawlat 'isra:'i:l kullama: tatallaba

11. al-amr.

12. 'inna hada al-baya:n sa:ri: al-maf'u:l li-

13. hi:n 'awdat al-hudu' 'ila al-mintaqa.

14.

15. qiya:dat jayš al-difa:' al-'isra:'i:liyy
Defense Force is determined to protect the citizens of the State of Israel as necessary.

This statement is valid until the return of calm to the region.

Israeli Defense Forces Headquarters

Parallel to the structure introduced by Faudree $(2012,188)$, when examining these leaflets as part of a larger collective body of Israeli military discourse, I suggest a recurrent structure for these texts containing four constituent parts:

1 Position Palestinian resistance fighters as the recurrent source of regional tension

2 Project the right of the military to protect its citizens

3 Establish the onus of responsibility for safety as a primarily civilian concern

4 Promise of violence if military warnings go unheeded

In the example above the opaque term 'ana:șir 'elements' (line 4) surfaces again, with the same level of indeterminacy as in the SMS message sent to Baker's father. Following this initial form of indeterminacy, by establishing the first part of the framework through positioning Palestinian fighters as the source of tension (lines 5-7) the military is able to solidify and maintain the second part of the structure, the right of the military to protect Israeli civilians (lines 7-9).

The third part of this textual architecture (lines 3-5) plays a major role in shifting the participant framework of the conflict by placing the responsibility for safety on civilians themselves, while insinuating a relationship between civilians and the resistance fighters that Israel has engaged in combat. Finally, the fourth part of this framework provides a warning (lines 8-9) to recipients of the message that violence will continue if the messages in the texts are ignored. Beyond establishing the fourth part of the textual structure, the military notes (lines 12-13) that their promise of violence is valid until calm returns to the area, but what constitutes calm and who makes that decision, remains ambiguous. We can only assume, given their position of power, that the military views themselves as the arbiters in determining when the present round of conflict will abate. While the order in which the structure is established varies, with multiple constituent parts at times being established by similar passages in the texts, the use and development of this framework allows the military to inject layers of indeterminacy into the conflict, both in its participant framework and into the texts themselves.

As was the case with the SMS message sent to Baker's father, the participant framework of this leaflet is ambiguous. The leaflet is addressed to the residents of the Gaza Strip, but it is unclear from the language of the message whether they are viewed as participants in or victims of the conflict. Superficially, this leaflet projects the residents as victims of the fighting that Hamas has brought upon the Gaza Strip. However, the indeterminacy that abounds regarding what the military considers a legitimate target in Gaza simultaneously positions the residents of the Strip in a liminal space somewhere between victim and participant. The leaflet instructs the residents of Gaza to negotiate their positionality within this indeterminate framework, making a choice regarding what to do after receiving the leaflet. ${ }^{16}$ In engaging with the leaflet and subsequently making that choice, civilians are further drawn into the participant framework of the conflict, or in Das' $(2004,229)$ terms the "gravitational force" of the state and through the sheer existence, use, and circulation of the leaflet, military action is licensed (Faudree 2012, 190; Spitulnik 1997). 
These military leaflets and the method by which they are delivered to Gazans also parallels the power dynamic of the conflict, a point mentioned at the outset of this analysis. The leaflets are typically distributed by drones or fighter jets: the same machines that may later drop explosives in Gaza are used to drop warnings for its residents. The use of the same machines to carry out seemingly contradictory aims reflects yet another layer of the indeterminacy present in the Gazan context. By examining another example, also from Operation Cast Lead in 2008-9, we see how even though certain forms of indeterminacy may recede, the overall indeterminate participant framework is maintained through a process of layering new forms of indeterminacy into the text and onto its recipients:

\section{Example 3: Lend a helping hand, Operation Cast Lead (2009) ${ }^{17} 18$}

1. 'ila sukka:n qita:' ġazza

2. tahammalu al-mas'u:liyya 'an mași:rikum!

3. 'inna muṭliqi: al-ṣaw:ari:x wa al-'ana:șir

4. al-'irha:biyya yušakkilu:n xatar-an

5. 'alaykum 'ala 'a:'ila:tikum.

6.

7. 'ida kuntum tagribu:n fi: taqdi:m 'ayd

8. al-'awn wa al-musa: 'ada li-'aha:li:kum wa

9. 'ixwa:nikum fi: al-qita:' ma: 'alaykum 'illa:

10. al-ittiṣa:l 'ala al-raqam 'adna:h $l-$

11. ittila: 'ina 'ala mawa:qi' minașsa:t

12. al-șawa:ri:x wa al- 'iṣa:ba:t al-'irha:biyya

13. allati ja'alat minkum rahi:na li-

14. 'amali:ya:tiha:

15.

16. mana'a waqawa'a al-fa:ja 'a aṣbah bayna

17. 'aydi:kum.

18.

19. la: tataraddadu:!

20. sa-nurahhib bi-jami:' al-ma'lu:ma:t

21. bidu:n al-ha:ja 'ila 21. dikr tafa:și:likum

22. al-šaxși:yya.

23. al-sirri:yya madmu:na.

24. yumkinukum al-ittișa:l bina: 'abra al-

25. raqam al-ta:li: 02-5839749

26.'aw 'ala: al- 'unwa:n al-ta:li:

27.helpgaza2008@gmail.com

28. li-taqdi:m 'ayy ma'lu:ma ladaykum 'an

29. naša:t al-'ana:șir al-'irha:biyya

30.

31. qiya:dat jayš al-difa: ' al-'isra:'i:liyy
To the residents of the Gaza Strip

Take responsibility for your fate!

Rocket launchers and terrorist elements pose a threat to you and your families.

If you want to lend a helping hand and assist your brothers and sisters in the Strip, then contact the number below to let us know the location of rocket launchers and terrorist gangs that made you hostage to their operations.

Preventing the tragedy from happening is in your hands.

Do not hesitate!

We will welcome all available information without the need to mention your personal details

Confidentiality assured.

You can contact the following number: 02-5839749

And the following email address:

helpgaza2008@gmail.com

To provide any information you have about the activity of terrorist elements.

Israeli Defense Force Headquarters

As with the leaflet in example 2, we can see the constituent parts of the structure that I have outlined above being established anew in example 3. The first constituent part of the structure, positioning Palestinian fighters as a source of regional tension is implicitly established (lines 3-4) through language that describes them as a threat. In doing so, the right of the military to respond, the second part of the structure, is also established. The third part of the structure is solidified (lines 2 and 16) through describing responsibility as being in the hands of civilians and imploring them to avoid bloodshed. This mention of bloodshed (line 16) also establishes an implicit promise of violence if this message is ignored, completing the remaining component of the overarching structure of these texts. Although 'ana:sir 'elements' is used again in this example, rocket launchers are also mentioned (lines 3 and 10), providing a slightly more concrete notion of what constitutes a terrorist element to the IDF. 
This leaflet also actively solicits collaboration (line 10) from Gazan civilians to assist in Israel's military campaign, a crime that, in Gaza, is punishable by death. ${ }^{19}$ This leaflet is a departure from the other texts examined thus far, in that the participant framework has shifted slightly. While earlier examples positioned Gazan residents in an indeterminate or liminal position in relation to both the IDF and Hamas fighters, that is not the case in example 3. Here, the text positions the residents of Gaza closer to victims. Crucially, however, they are not victims of Israeli strikes, but victims of "terrorist gangs" (lines 10-11) operating in Gaza that the military would like civilians to help them eradicate. In drawing civilians into the scope of the state (Das 2004) by soliciting collaboration, the state contrasts civilians with terror elements in Gaza, reifying the notion of a 'margin' that "represents a zone of instability and danger precisely because it lies outside both the control and territory of the national state" (Poole 2004, 54).

The promise of anonymity (lines 20-22) from the IDF, which can be seen as welcoming the development of a relationship based on trust, is also made indeterminate when viewed in light of the relative ease with which Israeli intelligence officials have been able to tap into the Gazan telecommunications infrastructure (Tawil-Soury 2013; Weizman 2009b). Additionally, the use of email introduces electronic indeterminacy into the relationship between the recipients of this leaflet and the military. Through email the military opens a direct line of communication with civilians, establishing the potential for a personal connection between two disparate groups.

However, the connection suggested by the leaflet keeps the identities of Israeli officials receiving the messages hidden, while further undermining their offer of anonymity through the military's access to a personal detail that the leaflet describes as not required, an email (or Internet Protocol) address. In a sense this is yet another manifestation of the power imbalance in the conflict, this time through doublevoicing (Bakhtin 1981, 324) which here protects Israeli officials while opening up a space whereby potential collaborators are vulnerable. In this leaflet, the military can offer confidentiality and anonymity to those Gazans willing to collaborate, but collaboration implies necessarily giving up your anonymity by providing contact information, which can then be tracked by the military. This is reified further by the frequency with which would-be one-time collaborators are pursued by intelligence offers to extract additional information regarding militant activities in Gaza. ${ }^{20}$ The two remaining leaflets, both from Operation Protective Edge in July-August 2014, add new layers of indeterminacy to the participant structure by positioning civilians as simultaneously complicit in, and victims of the most recent round of violence.

Example 4: The battle is ongoing, Operation Protective Edge $(2014)^{21}$

1. 'ila: sukka:n al-qiț:'

2. 'alaykum naql ha: dihi al-risa:la 'ila

3. qa:datikum al-muxtabi'i:n taht al-'ard

4. al-ma'raka maftu:ha

5.

6. kull 'afra:d qa:dat hama:s wa ba:qi:

7. al-haraka:t al'-irha:biyya gayr 'a:mini:n

8.

9. jayš al-difa:' al-'isra:'i:liyy
To the population of the Strip

Transfer this message to your leaders hiding underground:

The battle is ongoing

All members of the Hamas leadership and the leaderships of other terrorist movements are not safe

The Israel Defense Forces

Unlike earlier examples, which showed more overt linguistic manifestations of the constituent structure developed for these texts, the participant structure in example 4 is implied rather than explicit. From this example we see that the IDF views Hamas and other resistance organizations in Gaza as aggressors in the conflict. By noting (lines 4 and 7) that the battle is ongoing and that militants are not safe we discern that 
the IDF is actively engaged in what it views as a struggle to protect its own citizens. In describing (line 2-3) that this message, aimed at groups "hiding underground", is being transferred to the residents of Gaza the military successfully places responsibility on civilians for how the conflict unfolds. Finally, in concert with establishing the second part of the constituent structure, noting that the battle is ongoing (line 4) also implies that additional violence is forthcoming.

Through the manner in which the military places responsibility on civilians in example 4 and the specific mention that their leaders are in hiding underground, this example reflects a particular facet of the 2014 conflict that is perhaps more specific than earlier leaflets. During Operation Protective Edge, Palestinian militants made use of an expansive network of underground tunnels stretching from Gaza into Israel. This allowed Palestinian fighters to not only seek refuge from the fighting but also strike military and civilian targets inside of Israel. ${ }^{22}$ In light of this context, the mention of "hiding underground" could suggest that these tunnel-based military tactics are what the IDF is referring to, providing a substantially more concrete context for the message. However, another reading of these lines is possible. By describing them as hiding underground in a leaflet delivered to civilians, the message undermines Hamas' leadership abilities, portraying them as cowardly in the face of conflict. The reminder (line 4) that the conflict continues above ground is perhaps less of a reminder to Hamas and is aimed more directly at civilians, an attempt to suggest that their leadership has abandoned them. This example also echoes larger military discourses that characterize Hamas fighters as using their own citizens as shields in the fighting. ${ }^{23}$ It is unclear, however, if employing this type of discourse in a military leaflet successfully undermined Hamas' position in Gaza.

As the language discussed above suggests, this leaflet takes a decidedly different, and more aggressive tone towards the residents of the Gaza Strip than earlier examples. While the leaflet undermines Hamas' leadership ability, it also positions civilians as an intermediary between the military and Palestinian fighters by stating, "Transfer this message to your leaders hiding underground" (lines 2-3). The concern by the military evidenced through the language of the earlier leaflets is completely absent here, with the language of this message essentially implicating civilians in the wider conflict by placing them linguistically in the middle of a fight between a state military and a resistance organization.

The possible, varied readings for this leaflet simultaneously works against Hamas leadership while placing civilians in an uncertain position. The participant framework of the conflict shifts again in example 4 through language that positions civilians as complicit in the fighting. The remaining example is the least indeterminate and most legible of the data presented, but the overall structure and framing of these messages, which layers indeterminacies to strategically position both the military and civilians, remains apparent.

Example 5: You are hereby forewarned to exercise caution, Operation Protective Edge $(2014)^{24}$

1. bala:g 'askariyy 'ila sukka:n bayt la:hi:ya

2 .

3. bi-l-ragm min muba:darat waqf 'ițla:q al-

4. na:r ala: hama:s wa al-haraka:t al-

5. 'irha:biyya al-'uxra: istamirru: fi: ițla:qihim

6. al-na:r li-ha:da:

7.

8. sa-yaqu:mu jayš al-difa:' al-'isra:'i:liyy bil-

9. 'amal bi-quwwa wa 'azam li-l-darb min al-

10. jaww al-'ana:șir al-'irha:bi:yya wa al-

11. buna: al-tahti:yya al-ta:bi a la-ha: fi: al-

12. mana:tiq allati tuțlaqu min-ha al-șawa:ri:x
Military Announcement to the population of Beit Lahia

Despite the ceasefire initiative, Hamas and other terrorist movements continue to fire [on Israel].

Therfore:

The Israeli Defense Forces will work with strength and vigor to strike from the air terrorist elements and infrastructure in areas from which rockets are fired towards the State of Israel and they are as follows: 
13. bi-ittija:h dawlat 'isra:'i:l hiya ka-l-ta:li:

14.

15. min šarq 'ata:țara wa hatta: ša:ri'

16. al-sala:ti:n wa min garb wa šima:l

17. mu askar jaba:li:yya

18.

19. min 'ajl salama:tikum:

20. 'alaykum 'ixla:' buyu:tikum ha:lan wa

21. fawran wa al-ittija:h ila janu:b jaba:li:yya

22. al-balad 'ibra al-tari:q al-ta:li:

23.

24. ša:ri al-fa:lu:ja wa ha:da: hatta: al-sa: 'a

25. 12 J'uhur yawm al-'ahad 13.7.2014

26.

27. jayš al-difa: ' al-'isra:'i:liyy ġayr ma 'niyy

28. bi-l-lams bikum wa bi-'abna:' 'ale:kum

29. ha:dihi al-'amaliyya:t maw'aqata wa

30. qași:ra kul man sa-yaxa:lif ha:dihi a-

31. ta li:ma:t wa la: yaxli:

32. baytahu 'ala: al-fawr haya:tuhu wa haya:t

33. 'abna:' 'a:'ilatihi lil-xatar!!!!

34.

35. a dara man 'andara!

36.

37.

38. qiya:dat jayš al-difa: 'al-'isra:'i:liyy
From East of 'ața:țara to Sultans Street and from the West and North of Jabalia Camp.

For your safety:

Evacuate your homes immediately and go to the South of Jabalia city via the following way:

Fallujah Street as of $12 \mathrm{pm}$ on Sunday July 13th, 2014.

The Israeli Defense Forces is not interested in coming in contact with you and your families. These operations are [temporary and short]. All who counter these instructions and don't leave immediately are putting their lives and the lives of their families in danger!!!!

You are hereby forewarned to exercise caution!

Israeli Defense Forces Headquarters

In example 5 (lines 3-4), Palestinian resistance groups are again positioned as a source of tension, here through what the military describes as the violation of a ceasefire. This violation results (lines 8-12) in the military responding to rocket fire directed at Israel and its citizens. Responsibility for the safety of Gazan residents is placed again in the hands of civilians (lines 30-36), through language that suggests that those who do not immediately follow the leaflet's instruction are in mortal danger. Finally, by noting (lines 27-29) that the military does not want to come into contact with civilians, an implicit promise of further violence is established.

Further, the lexical indeterminacy of 'ana:șir 'elements' surfaces for a final time in this example. Despite the indeterminacy of 'ana:șir that has run as thread throughout many of these texts, this example actually provides the greatest degree of useable information for civilians regarding military operations. The leaflet (lines 15-16) specifies the areas of Beit Lahia, north of Gaza City, that have been targeted for strikes, providing street names and directions (lines 20-25) to the recipients of the leaflets as to where they should go to avoid potential airstrikes. This is a departure from the often ambiguous mentions of military strikes in the earlier examples.

In this leaflet the military again appears to occupy a position of concern for the safety of civilians within the participant framework of the conflict, a theme common in some of the examples analyzed above. This concern, although highly visible in this example, still does not displace one of the major forms of indeterminacy that has been covered in my analysis of these texts. Civilians in Beit Lahia, regardless of their actual relationship with Palestinian resistance groups, are again located as an intermediary between the military and these organizations through the structure of the text.

Although they are not the expressed recipient of the message, in these forms of communication resistance organizations are made ratified overhearers (Goffman 1981) in the sense that, once these messages are dropped in Gaza, they can be read by anyone who picks them up. However, by labeling civilians as the "official" recipients (Goffman 1981) of the message, the military again is able to position them as an intermediary between the IDF and Hamas. As I have argued above, through positioning the civilian recipients (Goffman 1981) of these messages as intermediaries 
in the wider shadow conversation taking place between the IDF and resistance groups regarding blame for the conflict, the military is able to continually and repeatedly shift the participant framework (Irvine 1996, 140).

Through the shifting and multiple layers of indeterminacy that have surfaced in this analysis, civilians remain in a space somewhere between non-combatant and participant, between the violence of the margins and the order and scope of the state. On the surface this final example removes the more flatly visible manifestations of indeterminacy that have been highlighted throughout the study. However, the final leaflet still fulfills all of the constituent parts of textual architecture laid out above. In doing so, this message highlights that in its essence this is an architecture built on, maintained, and proliferated through indeterminacy. Through this indeterminacy, language reinforces and supports the larger social hierarchies and power structures of what has become the world's most enduring protracted conflict.

\section{Conclusion: Prevent the tragedy from being on your hands}

Tawil-Soury and Matar (2016, 2-4) describe that throughout its history many metaphors and narratives have been ascribed to Gaza. Perhaps most vivid among these have been the presentation of Gaza as an open air prison, a metaphor which lays bare the refusal of the world to truly work toward solving the Israel-Palestine conflict. Gaza also offers a possible window into "Israel's contemporary weakness whether a weakness of its military to dispose of Gaza, or a weakness of morality in attempting to do just that" (Tawil-Soury and Matar 2016, 2). As they describe, Gaza "has always been and remains a problem for Israel" (Tawil-Soury and Matar 2016, 7). The coastal enclave has refused to be silenced, despite numerous attempts to relegate it permanently to the margins.

If Gaza refuses to be silenced, then, how should it be located when it is viewed alongside the enduring social and political project of maintaining the sovereignty of the Israeli state? Is it merely a violent thorn in Israel's side? Or perhaps it, and its present political leaders, are the primary barrier to both the security of Israel and the viability of a future Palestinian state? Variations on these themes certainly constitute much of the discourse that circulates about Gaza. However, I conclude by reiterating what I feel are perhaps the more salient characteristics of the data that I have presented. Indeterminacy has served as a thread that unites these varied texts. The SMS messages and leaflets presented here create a chain of communication between the military and Gazans, but this communication only travels from the upper levels of abstracted state power down to the daily lived reality of Gaza's residents. On the streets of Gaza where these texts are experienced, indeterminacy renders the state illegible (Das 2004, 244) through a complex process of shifting participant roles that puts civilians on perpetually uncertain footing.

The deployment of language in these forms and via the methods analyzed throughout this study creates spaces both locally and internationally where the state actively negotiates its relationship with its margins. Poole has argued that this relationship between the state "and its violent, extrajudicial, primitive, or natural 'margins' is simultaneously both accepted and denied as a more or less constant and central feature of the judiciary, and indeed of 'the state' in general" $(2004,51)$. I push Poole's statement further, arguing that Gaza is indispensable to Israel and cannot ever truly be relegated to its margins. A modern Israel cannot define itself without Gaza, despite mainstream political discourse's attempts to situate it forever outside of the scope of the state and antithetical to democracy. Gaza has and continues to reinstate its centrality, as Tawil-Soury and Matar (2016) have described. However, this centrality transcends the levels of culture, history, or even the nature of international political regimes. Within its context, Gaza is essential to the emergence and maintenance of the state itself.

The state has utilized Gaza as a tool in the ongoing project of reifying its own status as a legible, locatable, sovereign democracy within the international 
community. Achille Mbembe has argued that "to exercise control over morality and to define life as the deployment and manifestation of power" $(2003,12)$ is an essential component of the maintenance of sovereignty. An analysis of language in this context highlights one means by which the state asserts that control. Das has described that "the iterability of writing, the citability of its utterances" $(2004,234)$ makes possible conditions under which new social practices come into being that allow the state to reproduce itself. The language present in the leaflets and SMS messages deployed in Gaza forms one component of a constellation of methods that are used by the state for this purpose. In doing so, these texts highlight not simply the power of the state to produce "killable bodies" (Agamben 1998; Das and Poole 2004, 13), rendering them as bare life, suggesting instead that Gaza represents not a state of exception, a margin, but that it is embedded in every sense in the life of the state (Das and Poole 2004, 13).

\section{Notes}

1. I offer sincere thanks to Jennifer Roth-Gordon for her critical feedback on earlier versions of this manuscript, which pushed my thinking on the topic in new and interesting directions. In addition, I would like to thank Mary-Caitlyn Valentinsson, Uri Horesh, Jessica Ray, and Saqer al-Ammari for their comments on various drafts. Over the course of revision, the manuscript also benefited greatly from further suggestions from Micah Hughes, Nancy Hawker, the editors, and the two anonymous reviewers. Finally, I would like to thank the individuals who I had the opportunity to speak with during my time in Gaza. Any remaining errors are, of course, my own.

2. Transcription was carried out based on the Encyclopedia of Arabic Language and Linguistics (Versteegh et al 2006) transcription protocol.

3. The content of the SMS can be retrieved from: http://972mag.com/idf-sends-text-messa ge-to-gaza-mobile-phones-the-next-phase-is-on-the-way/60046/ (accessed 21 January 2017)

4. With the advent of technology and in particular social media, this is actually changing. Still, official military communication remains a domain for Standard Arabic.

5. In a sense these texts fall into the larger collective of Arabic language materials published by the Israeli state, given that Arabic is one of the official languages of the state of Israel, even though Gaza's residents are not Israeli citizens.

6. A 2015 report by the United Nations Development Program shows that in general, literacy rates among Palestinians, and specifically in Gaza are high. However vulnerable groups, namely the elderly, children, and women show the highest illiteracy rates across the Palestinian community. http://www.ps.undp.org/content/dam/papp/docs/Publications/ UNDP-papp-research-PHDR2015Education.pdf (accessed 21 January 2017).

7. The IDF followed Jabari's assassination by uploading the video of the strike to its official Youtube channel: https://www.youtube.com/watch?v=P6U2ZQ0EhN4 (accessed 21 January 2017).

8. Gisha - Legal Center for Freedom of Movement regularly publishes updates regarding the situation in Gaza and in particular the state of the blockade: http://gisha.org/publication (accessed 21 January 2017).

9. Details of the process of calling civilians, along with the audio of a call made by an IDF officer to a civilian in Gaza is available on the IDF blog, however the call itself is in Hebrew and it is unclear from the audio if the recipient of the call actually understands Hebrew: https:// www.idfblog.com/blog/2014/07/16/idf-done-minimize-harm-civilians-gaza/ (accessed 21 January 2017)

10. 'Knocking on the roof' is a practice whereby the Israeli military drops a warning bomb on a structure marked for further airstrikes. The munition generally contains a non-explosive warhead that penetrates the upper level of a structure. Israeli military officials argue that the practice serves as a warning to civilians in structures marked by a 'knock on the roof' to exit the building and seek shelter before follow up air strikes.

11. IDF Blog - http://www.idfblog.com/blog/2012/11/15/how-does-the-idf-minimize-ha rm-to-palestinian-civilians/ (accessed 21 January 2017)

12. NBC - http://www.nbcnews.com/storyline/middle-east-unrest/israel-drops-leafletswarning-northern-gaza-airstrikes-n154571, and http://www.nbcnews.com/storyline/midd le-east-unrest/battle-ongoing-gaza-israel-leaflets-warn-n171551 (accessed 21 January 2017) 
13. Maan News - http://www.maannews.com/eng/ViewDetails.aspx?id=207440 (accessed 21 January 2017)

14. Haaretz - http://www.haaretz.com/news/diplomacy-defense/1.605421 (accessed 21 January 2017)

15. IDF Blog - http://www.idfblog.com/blog/2012/11/15/how-does-the-idf-minimize-ha rm-to-palestinian-civilians / (accessed 21 January 2017)

16. Similar linguistic moves are evident in the language of leaflets dropped by Syrian and Russian forces in advance of attempts by both militaries to retake Aleppo, Syria: https: / /www. nytimes.com/2016/11/29/world/middleeast/thousands-flee-onslaught-in-aleppo-as-assadsforces-gain-ground.html?_r=1, and https://www.thesun.co.uk/news/2117306/russians-dropwarning-leaflets-ahead-of-massive-aleppo-blitz-as-terrified-families-tell-the-world-to-pray-for-us / (accessed 21 January 2017)

17. http://www.maannews.com/eng/ViewDetails.aspx?id=207440 (accessed 21 January 2017)

18. The leaflet contains a typo, the Arabic word 'ayd hand', which appears to have been misspelled in the original

19. One of the most recent examples of how seriously collaboration is dealt with in Gaza is exemplified in a case from 2014, where 18 suspected collaborators were killed by Hamas authorities: http://www.wsj.com/articles/hamas-kills-18-alleged-collaborators-1408715295 (accessed 21 January 2017)

20. Multiple international news sources have detailed the practice of blackmailing Palestinian residents into becoming collaborators with the Israeli military and intelligence service. The Guardian provides one example: https://www.theguardian.com/world/2014/se p/12/israeli-intelligence-unit-testimonies (accessed 21 January 2017)

21. http:/ / www.nbcnews.com/storyline/middle-east-unrest/battle-ongoing-gaza-israelleaflets-warn-n171551 (accessed 21 January 2017)

22. http:/ / america.aljazeera.com/opinions/2014/7/gaza-tunnels-hamasisraelidf.html (accessed 21 January 2017)

23. The IDF, in the period surrounding the 2014 conflict published numerous articles on its official blog detailing what it reported was Hamas' use of human shields: https://www.idfb log.com/2014/08/27/hamas-terrorists-confess-using-human-shields/ (accessed 21 January 2017).

24. http:/ / www.nbcnews.com/storyline/middle-east-unrest/israel-drops-leaflets-warningnorthern-gaza-airstrikes-n154571 (accessed 21 January 2017)

\section{References}

Agamben, Giorgio.

1998. Homo Sacer: Sovereign Power and Bare Life. Stanford: Stanford University Press.

Amnesty International.

2009. Operational 'Cast Lead': 22 Days of Death and Destruction. https://www.amnesty.org/ en/documents/MDE15/015/2009/en/ (accessed 21 January 2017).

Asad, Talal.

2007. On Suicide Bombing. New York: Columbia University Press.

Bakhtin, Mikhail.

1981. The Dialogic Imagination, edited by Michael Holquist. Austin: The University of Texas Press.

Benjamin, Medea.

2013. Drone Warfare: Killing by Remote Control. London: Verso.

Das, Veena, Arthur Kleinman, Mamphela Ramphele, and Pamela Reynolds, eds.

2000. Violence and Subjectivity. Oakland: University of California Press.

Das, Veena.

2004. "The Signature of the State: The Paradox of Illegibility." In Anthropology in the Margins of the State, edited by Veena Das and Deborah Poole, 225-252. Santa Fe: School for Advanced Research Press.

Das, Veena, and Deborah Poole.

2004. "State and Its Margins." In Anthropology in the Margins of the State, edited by Veena Das and Deborah Poole, 3-33. Santa Fe: School for Advanced Research Press.

Falk-Moore, Sally.

1978. Law as Process. Boston: Routledge and Kegan Paul 
Faudree, Paja.

2012 "How to Say Things with Wars: Performativity and Discursive Rupture in the Requerimiento of the Spanish Conquest." Journal of Linguistic Anthropology 22(3):182-200.

Gavriely-Nuri, Dalia.

2013. The Normalization of War in Israeli Discourse, 1967-2008. Plymouth: Lexington Books.

2015. Israeli Peace Discourse: A cultural approach to CDA. Amsterdam: John Benjamins.

Goffman, Erving.

1981. Forms of Talk. Philadelphia: University of Pennsylvania Press.

Green, Linda.

1999. Fear as a Way of Life: Mayan Widows in Rural Guatemala. New York: Columbia University Press.

Halper, Jeff.

2000. "The 94 Percent Solution." Middle East Report 216(Autumn): 14-19.

Hanke, Lewis.

1949. The Spanish Struggle for Justice in the Conquest of America. Philadelphia: University of Pennsylvania Press.

Helps, Arthur.

1971 [1900]. The Spanish Conquest in America and Its Relation to the History of Slavery and to the Government of the Colonies. Vol. I. Detroit: Negro History Press.

Hodges, Adam.

2011. The "War on Terror" Narrative: Discourse and Intertextuality in the Construction and Contestation of Sociopolitical Reality. Oxford: Oxford University Press.

Holes, Clive.

2004. Modern Arabic. Washington, DC: Georgetown University Press.

Irvine, Judith T.

1996. "Shadow Conversations: The Indeterminacy of Participant Roles." In Natural Histories of Discourse, edited by Michael Silverstein and Greg Urban, 131-159. Chicago: University of Chicago Press.

Jaffe, Alexandra M.

2009. "Indeterminacy and regularization: a process-based approach to the study of sociolinguistic variation and language ideologies." Sociolinguistic Studies 3(2): 229-251.

Kaag, John, and Sarah Kreps.

2014. Drone Warfare. Malden, MA: Polity Press.

Levine, Mark.

2005. Overthrowing Geography: Jaffa, Tel-Aviv, and the Struggle for Palestine 1880-1948. Berkeley: University of California Press.

Mbembe, Achille.

2003. "Necropolitics." Public Culture 15(1): 11-40.

Morris, Benny.

2008. 1948: A History of the First Arab-Israeli War. New Haven: Yale University Press.

Pappé, Ilan.

2006. The Ethnic Cleansing of Palestine. Oxford: Oneworld.

Poole, Deborah.

2004. "Between Threat and Guarantee: Justice and Community on the Margins of the Peruvian State." In Anthropology in the Margins of the State, edited by Veena Das and Deborah Poole, 35-65. Santa Fe: School for Advanced Research Press.

Roy, Sarah.

2007. Failing Peace: Gaza and the Palestinian-Israeli Conflict. London: Pluto Press.

Scheper-Hughes, Nancy.

1993. Death Without Weeping: The Violence of Everyday Life in Brazil. Oakland: University of California Press.

Silverstein, Michael.

1981. "Metaforces of Power in Traditional Oratory." Lecture, Department of Anthropology. Yale University, New Haven, CT.

Spitulnik, Debra.

1997. "The Social Circulation of Media Discourse and the Mediation of Communities." Journal of Linguistic Anthropology 6(2): 161-187.

Tawil-Soury, Helga.

2013. "Digital Occupation in Gaza's High-Tech Enclosure." In State Power 2.0: Authoritarian Entrenchment and Political Engagement Worldwide, edited by Muazzamil Hussain and Philip Howard, 57-68. Surrey: Ashgate Publishing Limited 
Tawil- Soury, Helga, and Dina Matar, eds.

2016. Gaza as Metaphor. London: Hurst \& Company

Taylor, Philip.

2003. Munitions of the Mind: A history of propaganda from the ancient world to the present era. Manchester: Manchester University Press.

Versteegh, Kees, Mushira Eid, Alaa Elgibali, Manfred Woidich, and Andrzej Zaborski, eds. 2006. Encyclopedia of Arabic Language and Linguistics, vol. 1. Leiden: BRILL.

Weizman, Eyal.

2009a. "Lawfare in Gaza: Legislative Attack." Open Democracy. Available at: https://www. opendemocracy.net/article/legislative-attack (accessed 21 January, 2017)

2009b. "Thanato-tactics." In The Power of Inclusive Exclusion: Anatomy of Israeli Rule in the Occupied Palestinian Territories, edited by Adi Ophir, Michal Givoni and Sari Hanafi, 543-574. New York: Zone Books.

2011. The least of all possible evils: Humanitarian violence from Arendt to Gaza. London: Verso. 